\title{
Recent Glacier Retreat Exceeds Internal Variability
}

\author{
B. K. Reichert* AND L. Bengtsson \\ Max Planck Institute for Meteorology, Hamburg, Germany \\ J. OeRlemans \\ Institute for Marine and Atmospheric Research Utrecht, Utrecht, Netherlands
}

(Manuscript received 27 August 2001, in final form 4 April 2002)

\begin{abstract}
Glacier fluctuations exclusively due to internal variations in the climate system are simulated using downscaled integrations of the ECHAM4/OPYC coupled general circulation model (GCM). A process-based modeling approach using a mass balance model of intermediate complexity and a dynamic ice flow model considering simple shearing flow and sliding are applied. Multimillennia records of glacier length fluctuations for Nigardsbreen (Norway) and Rhonegletscher (Switzerland) are simulated using autoregressive processes determined by statistically downscaled GCM experiments. Return periods and probabilities of specific glacier length changes using GCM integrations excluding external forcings such as solar irradiation changes, volcanic, or anthropogenic effects are analyzed and compared to historical glacier length records. Preindustrial fluctuations of the glaciers as far as observed or reconstructed, including their advance during the "Little Ice Age," can be explained by internal variability in the climate system as represented by a GCM. However, fluctuations comparable to the present-day glacier retreat exceed any variation simulated by the GCM control experiments and must be caused by external forcing, with anthropogenic forcing being a likely candidate.
\end{abstract}

\section{Introduction}

Quantifying natural climate variability and understanding the underlying physical mechanisms are major scientific goals of current climate research, also with respect to the investigation of anthropogenic impacts on climate. Examples for preindustrial climatic variations over the past millennium are climate epochs in Europe and neighboring regions with predominantly cold periods during roughly the seventeenth-nineteenth and warm periods during the eleventh-fourteenth centuries, often referred to as the "Little Ice Age" and the "Medieval Warm Period" (Lamb 1977; Grove 1988), respectively, although the timing of these periods for different regions of the globe has been questioned and demonstrated to vary considerably (Bradley and Jones 1993; Hughes and Diaz 1994; Folland et al. 2001, their section 2.3).

What are the possible physical processes responsible for preindustrial climatic variations over the past mil-

\footnotetext{
* Current affiliation: Lamont-Doherty Earth Observatory, Columbia University, Palisades, New York.
}

Corresponding author address: Dr. Bernhard K. Reichert, LamontDoherty Earth Observatory, Columbia University, 61 Route 9W, Palisades, NY 10964.

E-mail: reichert@1deo.columbia.edu lennium lasting for decades or centuries? Volcanic activity affects the global climate (Hansen et al. 1992; Lindzen and Giannitsis 1998), but only a series of major eruptions is likely to cool global temperature on decadal or longer timescales. Estimations of variability in solar irradiation (Lean et al. 1995; Hoyt and Schatten 1993) are based on indirect and fragmentary evidence but may explain global temperature changes at a level of a few tenths of a degree (Cubasch et al. 1997). However, it appears that a dominant part of climatic variability over the past millennium may be explained by internal variability in the climate system. Hasselmann (1976) demonstrated that low-frequency variations in a system such as the climate could simply be the integrated response of a linear (or nonlinear) system forced by short-term variations resulting, for example, from the macroturbulent atmospheric flow at midlatitudes. The dynamics of a physical system can turn short-term stochastic forcing into low-frequency climate variability. This has been demonstrated using ocean general circulation models (Mikolajewicz and Maier-Reimer 1990) and is also applicable to the dynamic response of glacier systems (Paterson 1994) as investigated in this study. Other possible mechanisms inherent to the climate system are internal ocean variability, ENSO variability, and other coupled atmosphere-ocean modes (Sarachik et al. 1996; Bengtsson and Reichert 2000; Bengtsson 2001). 
General circulation models (GCMs) integrated over long periods of time are essential tools in investigating the role of forcing factors. As an example, we investigate in this study to what extent fluctuations of specific glaciers in Europe (observed or reconstructed both prior to industrialization and within the twentieth century) can be explained by internal climate variations as simulated by a coupled GCM. External forcings such as solar irradiation changes, volcanic, or anthropogenic effects are excluded in the GCM experiments.

Glacier fluctuations result from changes in the mass and energy balance at the earth's surface and represent valuable paleoclimatic proxy data providing important information on climate variability over long periods of time. They are also key elements for the early detection of climate change and possible anthropogenic impacts on climate. Changes in glacier mass balance are defined as the annual mass gain or loss at the surface of a glacier (Paterson 1994). They can be viewed as the direct reaction of a glacier to climatic variations without delay. The mean specific mass balance of a glacier is the mass balance over the entire glacier surface. Mass balance variations are mainly sensitive to the seasonal distributions of both temperature and precipitation, with sensitivities varying enormously among individual glaciers. For example, for the maritime glacier Nigardsbreen (Norway), it has been shown (Reichert et al. 2001) that a $1^{\circ} \mathrm{C}$ higher temperature in summer [June-July-August (JJA)] can have the same effect on mean specific mass balance as $20 \%$ less precipitation in winter [DecemberJanuary-February (DJF)]. The process-based modeling approach applied in this study (Fig. 1) accounts for these strongly varying seasonally dependent sensitivity characteristics for individual glaciers (section 2).

Variations in glacier length are the indirect, delayed, filtered, and strongly enhanced response to climatic variations and are, therefore, much more difficult to interpret than glacier mass balance. However, the available records of observed or reconstructed historic glacier length fluctuations are much longer (often multicentennial) than available mass balance records (usually less than $50 \mathrm{yr}$ ). In order to be able to compare these long glacier length records to modeling studies, a dynamic ice flow model calculating the response of glacier geometry (including the position of the glacier front) to changes in specific mass balance is used in this study (section 3). We simulate specific glacier length fluctuations for the temperate valley glaciers Nigardsbreen (Norway; $61^{\circ} 43^{\prime} \mathrm{N}, 7^{\circ} 08^{\prime} \mathrm{E}$ ) and Rhonegletscher (Swiss Alps; $46^{\circ} 37^{\prime} \mathrm{N}, 8^{\circ} 24^{\prime} \mathrm{E}$ ) for comparison with historical records of glacier length (section 5). In order to simulate long, statistically significant records of low-frequency glacier length fluctuations, we introduce a method using autoregressive processes to generate multimillennia records of mass balance from temporally limited GCM integrations (section 4). We investigate the probability that preindustrial glacier length variations can be explained by internal fluctuations inherent to the climate

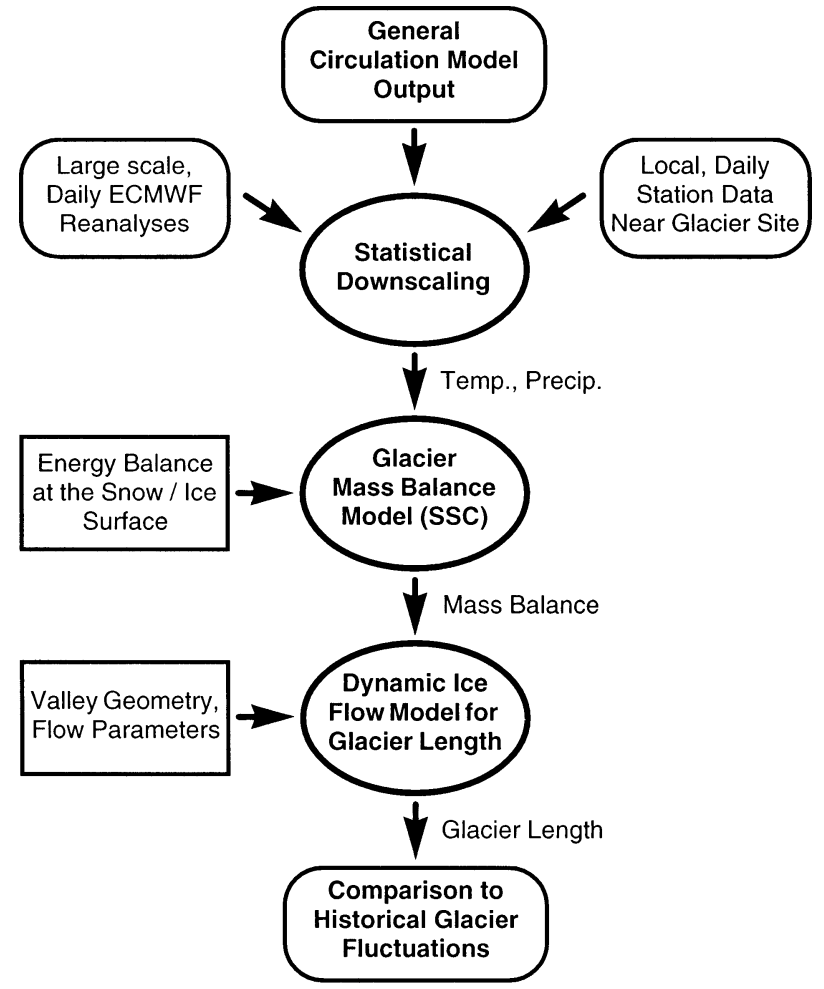

FIG. 1. Process-based modeling approach for the simulation of glacier fluctuations applied in this study. Statistically downscaled GCM integrations are used for mass balance calculations using glacier-specific seasonal sensitivity characteristics (SSCs) based on a mass balance model. Glacier length records are simulated using a dynamic ice flow model and can finally be compared to observed or reconstructed historical glacier fluctuations.

and the glacier system. We furthermore examine whether it is likely that the general retreat of the glaciers observed during the twentieth century, may be explained by internal variations as simulated by a GCM or whether additional external forcing, such as anthropogenic forcing, is required (sections 6 and 7).

\section{GCM experiments and simulation of mass balance}

We use statistically downscaled integrations of the coupled general circulation model ECHAM4/OPYC (Roeckner et al. 1996, 1999) thereby extending studies assuming purely white-noise climatic forcing (Oerlemans 2000, 2001). The atmospheric model ECHAM4 has 19 levels in the vertical extending up to $10 \mathrm{hPa}$. It is coupled to the full ocean general circulation model OPYC (Oberhuber 1993) consisting of three submodels for the interior ocean, for the surface mixed layer, and for sea ice (dynamic-thermodynamic sea ice model including viscous plastic rheology). The control integration used in this study has been integrated at T42 resolution (corresponding to a latitude-longitude grid of about $2.8^{\circ} \times 2.8^{\circ}$ ) excluding any external forcing such 


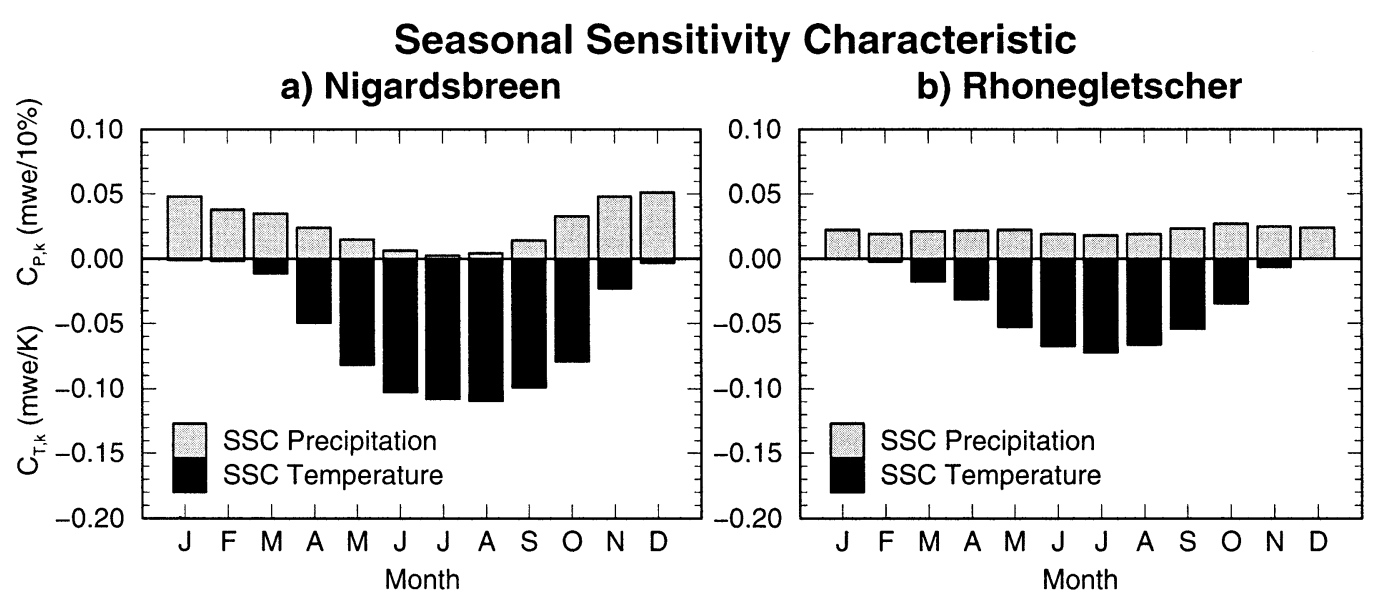

FIG. 2. Glacier-specific SSC for (a) Nigardsbreen and (b) Rhonegletscher (Reichert et al. 2001). The SSC represents the dependence of glacier mass balance on monthly perturbations in temperature [solid bars; unit: mwe $\mathrm{K}^{-1}$, where mwe means meter water equivalent] and precipitation [shaded bars; unit: mwe $(10 \%)^{-1}$ ].

as solar irradiation changes, volcanic, or anthropogenic effects. The concentrations of carbon dioxide, methane, and nitrous oxide are fixed at the observed 1990 values (Houghton et al. 1990, their Table 2.5). After a 100-yr spinup, the model has been integrated with constant flux adjustment for $300 \mathrm{yr}$ (Roeckner et al. 1999). Statistical downscaling of GCM integrations is based on daily reanalyses of the European Centre for Medium-Range Weather Forecasts (ECMWF; Gibson et al. 1997) and weather station data in the vicinity of the investigated glaciers, a detailed description of the method can be found in Reichert et al. (1999).

A process-based modeling approach using a mass balance model of intermediate complexity (Oerlemans 1992) and glacier-specific seasonal sensitivity characteristics (SSCs; Oerlemans and Reichert 2000) is applied in order to simulate glacier mass balance for Nigardsbreen and Rhonegletscher. The SSCs represent the dependence of the mean specific mass balance on monthly perturbations in temperature and precipitation and have been calculated from the process-based mass balance model, individually for each glacier.

The SSCs for Nigardsbreen and Rhonegletscher are shown in Fig. 2. For the maritime glacier Nigardsbreen (Fig. 2a), the melt season especially on the lower parts of the glacier is long, the sensitivity to changes in temperature is high from May to October. Temperature anomalies during these months lead to a strong response in mass balance whereas temperature changes in winter (DJF) have almost no effect since melting hardly occurs. The sensitivity of mass balance to relative changes in precipitation is very low in summer (JJA) since summer precipitation falls as rain over most parts of the glacier. In winter, precipitation mainly falls as snow and can be added to the surface, naturally leading to a strong effect on the annual mass balance.

Since the accumulation area of Rhonegletscher (Fig. $2 b)$ is located at higher altitudes $(2140-3620 \mathrm{~m})$ com- pared to Nigardsbreen (295-1950 m), lower annual air temperatures at the equilibrium line of the glacier (characterizing the glacier in its climatic and topographic setting) lead to a considerable effect also of summer precipitation (with a large fraction falling as snow at these altitudes). The sensitivity is in fact almost constant over the entire year. With respect to changes in monthly temperature, Rhonegletscher is generally less sensitive than Nigardsbreen.

Further details on the mass balance model, individual simulations using the SSCs, model validation using ECMWF reanalyses, and the impact of the North Atlantic Oscillation (NAO) on mass balance fluctuations of Nigardsbreen and Rhonegletscher are provided in Reichert et al. (2001). The study revealed a high correlation between decadal variations in the NAO and mass balance, with winter precipitation associated with the NAO being the dominant factor. A high NAO phase means enhanced (reduced) winter precipitation for $\mathrm{Ni}$ gardsbreen (Rhonegletscher), typically leading to a higher (lower) than normal annual mass balance. It has been found that this mechanism can also explain observed strong positive mass balances for Nigardsbreen and other maritime Norwegian glaciers within the period 1980-95.

\section{The ice flow model}

In order to be able to use long records of historic glacier fluctuations for comparison with model experiments, a dynamic ice flow model is needed. It calculates the response of glacier geometry to changes in specific mass balance. Cumulative glacier mass changes lead to changes in ice thickness that then influence the dynamic redistribution of mass by glacier flow (Haeberli 1995). In the following, a brief description of the ice flow model used in this study (Oerlemans 1997) is presented.

The prognostic equation of the ice flow model is a 
continuity equation describing conservation of ice volume:

$$
\frac{\partial S}{\partial t}=-\frac{\partial(U S)}{\partial x}+\omega B
$$

Here, $x$ is the coordinate along the flowline of the glacier, $U$ is the vertical mean ice velocity, $S$ is the area of a cross section through the glacier perpendicular to the flowline (parameterized by a trapezoidal cross section), $B$ is the mass balance, and $\omega$ is the glacier width at the surface.

Both simple shearing flow and sliding are considered in the model. The vertical mean ice velocity $U$ is determined by the local "driving stress" $\tau$ that is proportional to ice thickness $H$ and surface slope $\partial h / \partial x$ ( $h$ is surface elevation). After rearrangement of equations (Oerlemans 1997) it follows that ice thickness $H$ is governed by a nonlinear diffusion equation that has to be solved by the ice flow model:

$$
\frac{\partial H}{\partial t}=\frac{-1}{\omega_{0}+\lambda H} \frac{\partial}{\partial x}\left[D \frac{\partial(b+H)}{\partial x}\right]+B .
$$

Here, $H$ is the ice thickness, and $b$ and $\omega_{0}$ are the elevation and the width of the bed of the glacier, respectively. The $\lambda$ is determined by $\left(\omega-\omega_{0}\right) / H$. The diffusivity $D$ can be expressed as

$$
D=\left(\omega_{0}+\frac{\lambda}{2} H\right)\left[f_{d} \gamma H^{5}\left(\frac{\partial h}{\partial x}\right)^{2}+f_{s} \gamma H^{3}\left(\frac{\partial h}{\partial x}\right)^{2}\right],
$$

with $h$ as surface elevation, $f_{d}$ and $f_{s}$ as generalized viscosities referring to deformation and sliding, respectively, and $\gamma$ determined by $(\rho g)^{3}$ with ice density $\rho$ and acceleration due to gravity $g$.

The equations are solved using standard numerical methods for parabolic equations. Ice thickness, ice velocity, ice volume, and glacier length $L$ are obtained.

If a climatic state is changed stepwise from a state with equilibrium glacier length $L_{1}$ to a state with equilibrium glacier length $L_{2}$, the ( $e$ folding) response time for glacier length $t_{r L}$ is defined as the time the glacier needs to reach glacier length $L_{2}-\left(L_{2}-L_{1}\right) / e$. Using the above model, the response time of Nigardsbreen to a stepwise change in the annual mass balance $(\delta B=$ $\pm 0.4 \mathrm{~m}$ water equivalent; Oerlemans 1997) is $68 \mathrm{yr}$, for Rhonegletscher it is $61 \mathrm{yr}$.

\section{Autoregressive processes for the simulation of mass balance using GCMs}

In order to be able to quantify natural variations in glacier length with high statistical significance, long records of mass balance are required to force the dynamic ice flow model. Due to the long response times of the investigated glaciers (60-70 yr, see the previous section) mass balance time series in the order of thousands of years would be most suitable. However, the output of current coupled GCMs is naturally limited owing to high computational costs. For example, the ECHAM4/OPYC coupled GCM control integration used in this study has been integrated for $300 \mathrm{yr}$.

Owing to these limitations, in this study, we apply a method to generate multimillennia records of mass balance from temporally limited GCM integrations using autoregressive (AR) processes.

\section{a. General method}

An autoregressive process $X_{t}$ of the order $p$, that is, an $\operatorname{AR}(p)$ process, is generally defined as

$$
X_{t}=\alpha_{0}+\sum_{k=1}^{p} \alpha_{k} X_{t-k}+Z_{t},
$$

where $\alpha_{0}, \alpha_{1}, \ldots, \alpha_{p}$ are constants (autoregressive parameters), $\alpha_{p} \neq 0$, and $Z_{t}$ is a white-noise process. The name "autoregressive" indicates that the process evolves by regressing past values toward the mean (with a "strength" determined by the autoregressive parameters $\alpha_{k}$ and then adding noise (von Storch and Zwiers 1999).

We fit an AR process to the mass balance time series simulated from GCM output and generate a new mass balance time series of the desired length with similar properties. This involves 1) calculation of the autocorrelation function of the original time series, 2) fitting of an AR model to the time series, that is, estimation of the autoregressive parameters $\alpha_{k}$ (an iterative nonlinear least squares procedure incorporating backforecasting is used; Box and Jenkins 1976), and 3) generation of a new time series with a similar autocorrelation function and standard deviation as the original. This procedure is applied individually to the simulated mass balance records for Nigardsbreen and Rhonegletscher.

\section{b. AR processes applied to Nigardsbreen and Rhonegletscher}

The spectra of glacier mass balance as simulated by the GCM experiments (Reichert et al. 2001) are shown in Fig. 3. Thin solid lines denote the spectra of equivalent red-noise processes and dashed lines represent the 95\% confidence levels for accepting the red-noise null hypothesis. We generate 10000 -yr records of mass balance for the two glaciers with comparable frequency characteristics and similar standard deviations as the original time series.

We find that the mass balance time series for $\mathrm{Ni}$ gardsbreen simulated by the coupled GCM experiment can be well approximated by a third-order AR process (lag-1, lag-2, and lag-3 autocorrelation coefficients are 0.11 , Table 1 ). Neither simply white noise nor red noise would be appropriate for the representation of the lowfrequency characteristics of the mass balance time series. In fact, using a third-order AR process instead of 


\section{Simulated Glacier Mass Balance Spectra Downscaled GCM Control Run Excluding External Forcing}

a) Nigardsbreen

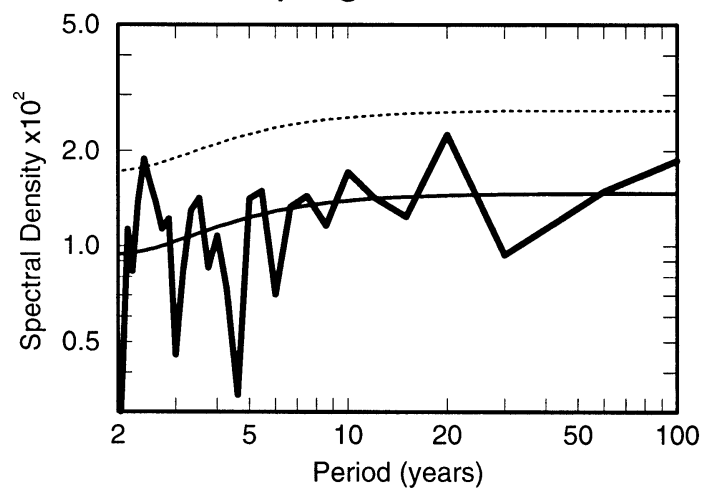

b) Rhonegletscher

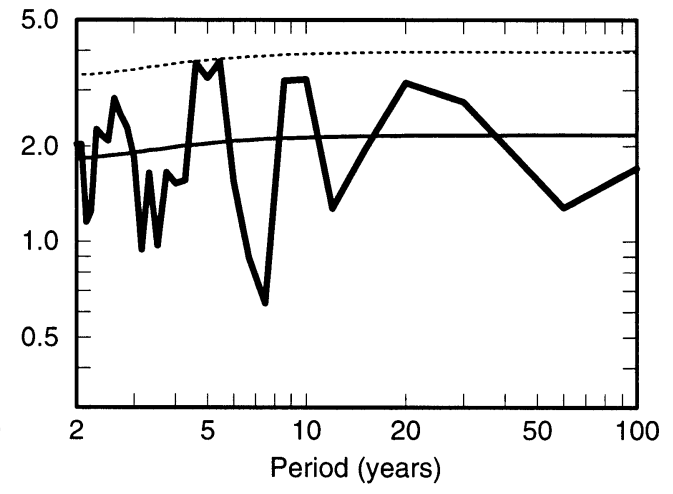

FIG. 3. Spectra of glacier mass balance records for (a) Nigardsbreen and (b) Rhonegletscher as simulated by the coupled GCM experiment. Thin solid lines denote the spectra of equivalent red-noise processes and dashed lines represent the $95 \%$ confidence levels for accepting the red-noise null hypothesis.

a simple white-noise process increases the variability in glacier length fluctuations by $36 \%$ as will be demonstrated in section 5. For Rhonegletscher, this impact is smaller, the simulated spectrum of mass balance may be approximated by a first-order AR process (lag-1 coefficient: 0.04; lag-2 and lag-3 coefficients: $<0.01)$. We can expect a small impact on low-frequency glacier length fluctuations as will be seen in section 5 .

Table 1 shows the autoregressive parameters $\alpha_{1}, \alpha_{2}$, and $\alpha_{3}$ as estimated by the AR model using the iterative nonlinear least squares procedure. A higher than thirdorder AR process is not required; we find that it does not significantly improve the fit of the model any further. The differences between the autocorrelation coefficients of the original and the generated mass balance records (Table 1; shown in parentheses) are small and not significant for the purpose of the present study.

\section{Simulation of glacier length fluctuations}

The 10 000-yr mass balance records using AR processes obtained from the coupled GCM are used to force the dynamic ice flow model for Nigardsbreen and Rhonegletscher. Again, it should be emphasized that the simulated glacier length records are exclusively due to

TABLE 1. Autocorrelation coefficients of the original GCM and of the generated $10000-y r$ mass balance records (in parentheses) using a third-order AR process determined by the AR parameters $\alpha_{1}$, $\alpha_{2}$, and $\alpha_{3}$ estimated by the AR model.

\begin{tabular}{lccc}
\hline \hline & \multicolumn{3}{c}{ Autocorrelation coefficients } \\
\cline { 2 - 4 } & Lag 1 & Lag 2 & Lag 3 \\
\hline Nigardsbreen & $0.11(0.12)$ & $0.11(0.12)$ & $0.11(0.11)$ \\
Rhonegletscher & $\alpha_{1}=0.091$ & $\alpha_{2}=0.089$ & $\alpha_{3}=0.092$ \\
& $0.04(0.04)$ & $0.003(0.002)$ & $0.004(0.003)$ \\
& $\alpha_{1}=0.044$ & $\alpha_{2}=-0.004$ & $\alpha_{3}=0.010$ \\
\hline
\end{tabular}

internal variations in the climate and glacier system since external forcing has been excluded in the GCM integration. We have simulated three individual 10000 yr glacier length records for each glacier in order to investigate the following:

1) the impact of using the AR process determined by GCM output instead of simply using white noise, and

2) the influence of using the statistically downscaled GCM integrations instead of simply interpolating coarse GCM gridpoint output to the location of the glaciers.

The results are presented in Fig. 4. Note that the time axes of the simulated records are not related to actual calendar years; we are solely interested in the possible range of internal glacier fluctuations. To facilitate the comparison with observations in the following section, the glacier model has been initialized to simulate variations around a mean level of observed preindustrial glacier lengths. The first glacier length record in each experiment [marked as "White Noise (Not Downscaled)" in the left part of each graph in Fig. 4] is simulated simply by using Gaussian white noise as mass balance forcing, with a standard deviation obtained from directly interpolated GCM gridpoint output without statistical downscaling. This means that the record represents glacier fluctuations that could be expected if neither the spectral characteristics of GCM output nor downscaling played any role. The second record in each experiment [marked as "AR Process (Not Downscaled)"] shows the impact of using a third-order AR process accounting for the spectral characteristics of the GCM integrations. The standard deviations of the mass balance forcing records are similar to the first record, statistical downscaling is not applied. The third record 


\section{Simulation of Glacier Length a) Nigardsbreen}

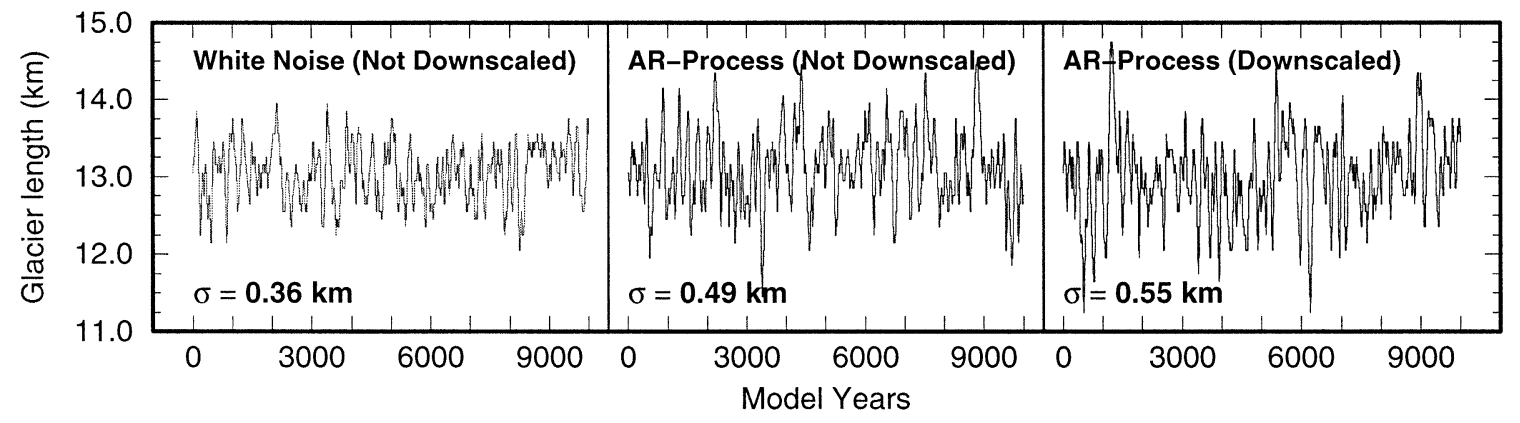

b) Rhonegletscher

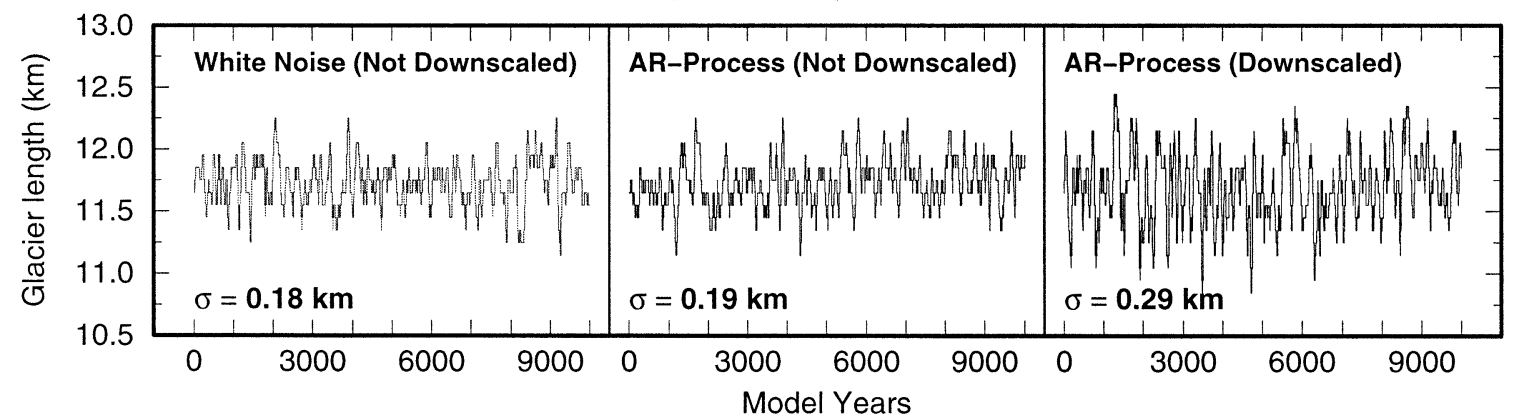

FIG. 4. The 10 000-yr records of simulated glacier length fluctuations for (a) Nigardsbreen and (b) Rhonegletscher. The figure demonstrates the impact of using AR processes determined by GCM output as mass balance forcing (middle record) instead of simply using white noise with the same variance (left-hand records), and the impact of statistical downscaling (right-hand records). Std devs $\sigma$ of glacier length are shown below each record.

[“AR Process (Downscaled)"] additionally considers the impact of statistical downscaling and is therefore considered as the most comprehensive representation of glacier fluctuations simulated in this study.

The standard deviations $\sigma$ of glacier length fluctuations for each experiment are shown below each record. For Nigardsbreen, using a third-order AR process determined from the coupled GCM experiment instead of a white-noise process (Fig. 4a) increases the variability in glacier fluctuations by $36 \%$ (standard deviations increase from 0.36 to $0.49 \mathrm{~km}$ ). As mentioned above, this emphasizes the high impact of the AR process for the generation of low-frequency glacier fluctuations. Statistical downscaling additionally increases the variability by another $12 \%$ (from 0.49 to $0.55 \mathrm{~km}$ ).

As could be expected from the almost white mass balance spectra of Rhonegletscher (Fig. 3b), the influence of the AR process on glacier length variations for this glacier is only marginal (Fig. 4b). However, due to the local setting of this glacier, the impact of downscaling is high, glacier length variability is increased by about $50 \%$ (from 0.19 to $0.29 \mathrm{~km}$; Fig. 4b). This shows the substantial influence of statistical downscaling in this region of the Alps (Reichert et al. 2001). With respect to local observational data, the direct coarse gridpoint output of a GCM would have considerably un- derestimated the local climatic variability responsible for the length fluctuations of this glacier.

\section{Comparison with observed glacier length fluctuations and statistical analysis}

Simulated glacier fluctuations are compared to observed historical glacier length records for Nigardsbreen and Rhonegletscher. Assuming that the occurrence of glacier fluctuations generally follows a Poisson process (events occur independently at random instants of time and at a constant mean rate per time interval; Priestley 1981), we investigate the probabilities of preindustrial glacier fluctuations on one hand and the present-day retreat of the glaciers on the other hand to be explained by internal variations in the climate system as simulated by the GCM.

\section{a. Historical records of glacier length changes}

Observed or reconstructed glacier length variations for the two glaciers are shown in Fig. 5. Various historic documents, terminal moraines, photogrammetric methods, and distance measurements have been combined to obtain this record (Hoelzle and Haeberli 1999).

During the first half of the eighteenth century, $\mathrm{Ni}$ - 


\section{Observed Glacier Length}

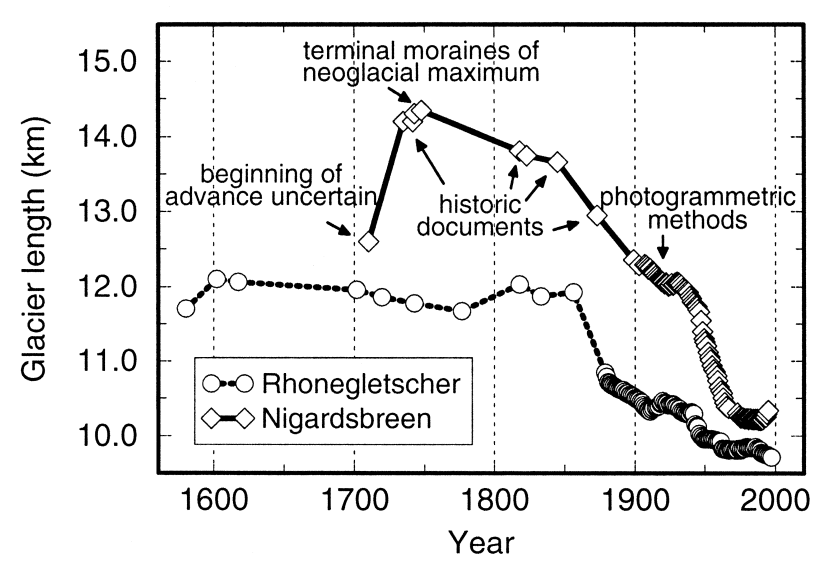

FIG. 5. Observed or reconstructed historical glacier length variations for Nigardsbreen (solid line; diamonds are data points) and Rhonegletscher (dotted line; circles are data points). Data from Hoelzle and Haeberli (1999).

gardsbreen advanced rapidly (the time of the beginning of the advance is uncertain) and reached a neoglacial maximum in 1748. Since then, a retreat has been observed until about 1990, which thereafter, came to an end. The retreat of the glacier until 1900 (in the following noted as "Little Ice Age to 1900 retreat") is about $2 \mathrm{~km}$ for Nigardsbreen. The retreat until 1990 ("Little Ice Age to present-day retreat") is roughly 4 $\mathrm{km}$.

Rhonegletscher advanced at the beginning of the records until 1602, followed by a period for which glacier length remained within a range of 11.6-12.1 km until 1860. This time then marks the beginning of a rapid retreat. The Little Ice Age to 1900 retreat of the glacier, considering its maximum in 1602 , is roughly $1.5 \mathrm{~km}$; the Little Ice Age to present-day retreat is about 2.3 $\mathrm{km}$.

\section{b. Analysis of simulated glacier fluctuations}

Figure 6 shows the first $2000 \mathrm{yr}$ of the simulated 10 000-yr glacier length records using AR processes including downscaling, along with the observations for Nigardsbreen (Fig. 6a) and Rhonegletscher (Fig. 6b). As for Fig. 4, the time axes of the simulated records are not related to actual calendar years, we are solely interested in the possible range of internal glacier fluctuations. The simulated records show substantial changes in glacier length lasting for decades or even several centuries. Nevertheless, it appears that the observed retreat of the glaciers since their Little Ice Age maximum exceeds any glacier fluctuation in the corresponding simulated records using the coupled GCM. Fluctuations in the order of reconstructed variations before $1900 \mathrm{do}$, however, occur in the simulated records and may therefore be explainable by internal climate variations as simulated by the GCM.
For a further analysis, recurrence relationships for specific glacier length fluctuations are calculated. The distribution of glacier fluctuations for the complete $10000-\mathrm{yr}$ records is shown in Fig. 7. Glacier length changes are calculated between a local extreme value and a subsequent "significant" extreme value, which means that continuous glacier length changes are considered until a significant reversal of the movement of the glacier tongue occurs. Significant means that only glacier length changes with amplitudes larger than one-half of the simulated standard deviation $\sigma(0.27 \mathrm{~km}$ for Nigardsbreen, $0.15 \mathrm{~km}$ for Rhonegletscher; Fig. 4) are considered to interrupt a continuing larger advance or retreat of the glacier. This emphasizes our interest in larger, longtime fluctuations; small interruptions within a movement (as, e.g., the observed small advance of Rhonegletscher at around year 1920; Fig. 5) do not affect the analysis. The velocity of the movement is not considered, slowdowns or standstills do not affect the analysis until a significant reversal of the glacier movement is initiated. The maximum change in glacier length over the complete simulated 10000 -yr records is an advance of $2.8 \mathrm{~km}$ for Nigardsbreen (Fig. 7a) lasting for about $200 \mathrm{yr}$ (Fig. 6a; at around model year +1200 ). For Rhonegletscher, the maximum change is a retreat of 1.3 km (Fig. 7b) lasting for more than $100 \mathrm{yr}$ (see Fig. 6b; at around model year +1900 ). The corresponding recurrence relationships are shown on a logarithmic scale in Fig. 8, the cumulative number of events $N$ is plotted against glacier length changes $\Delta L$. The relationships can be well approximated by exponential regression, the recurrence relationships can be expressed as

$$
\begin{array}{ll}
\log N=-1.77 \Delta L+5.46 & \text { (Nigardsbreen) and } \\
\log N=-2.96 \Delta L+5.45 & \text { (Rhonegletscher). }
\end{array}
$$

It may be noted that the largest simulated glacier length fluctuations $(\Delta L>2.5 \mathrm{~km}$ for Nigardsbreen and $\Delta L>1.1 \mathrm{~km}$ for Rhonegletscher; Fig. 8) are not completely in line with the regression. This can be expected since they occur only a few times within the $10000-y r$ records thus representing a sampling problem.

\section{c. Return periods of specific glacier length changes}

On the basis of the above established recurrence relationships, we determine return periods $\alpha$ for the occurrence of specific glacier fluctuations due to internal climate variations as simulated using the coupled GCM integrations:

$$
\alpha(\Delta L)=\frac{T_{\text {sim }}}{N(\Delta L)}=\frac{T_{\text {sim }}}{e^{b \Delta L+a}}=\left(T_{\text {sim }} e^{-a}\right) e^{-b \Delta L} .
$$

Here, $T_{\text {sim }}$ is the time period simulated (10 $000 \mathrm{yr}$ in our experiments), $a$ and $b$ are the glacier-specific regression parameters in the recurrence relationships (Nigardsbreen: $a=5.46, b=-1.77$; Rhonegletscher: $a$ $=5.45, b=-2.96$; see above).

Table 2 shows that glacier fluctuations of at least 


\section{Simulated and Observed Glacier Length Variations \\ a) Nigardsbreen}

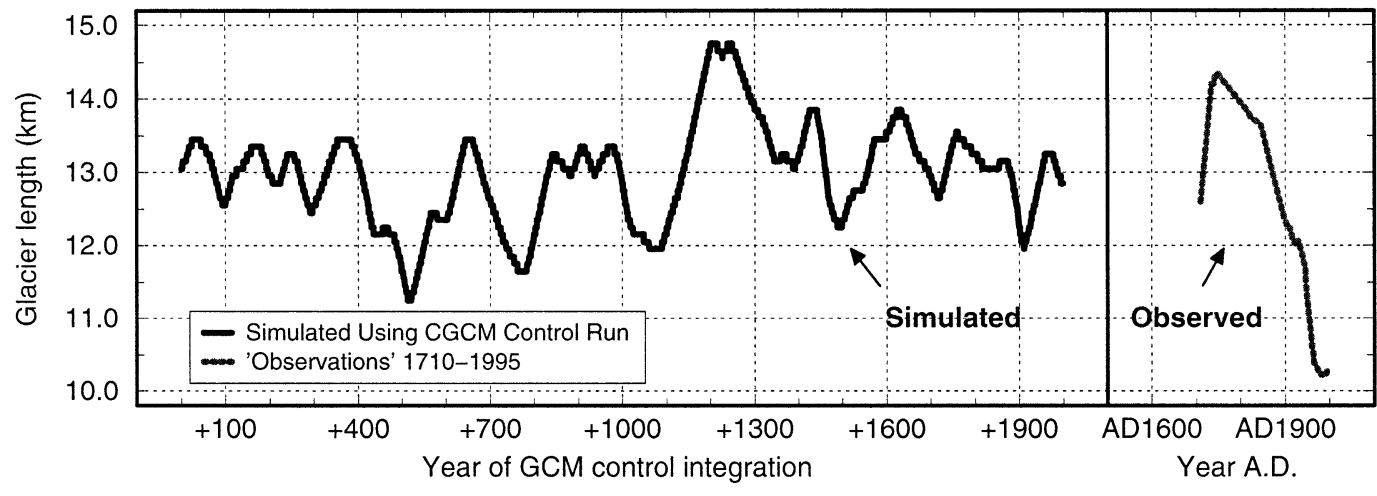

b) Rhonegletscher

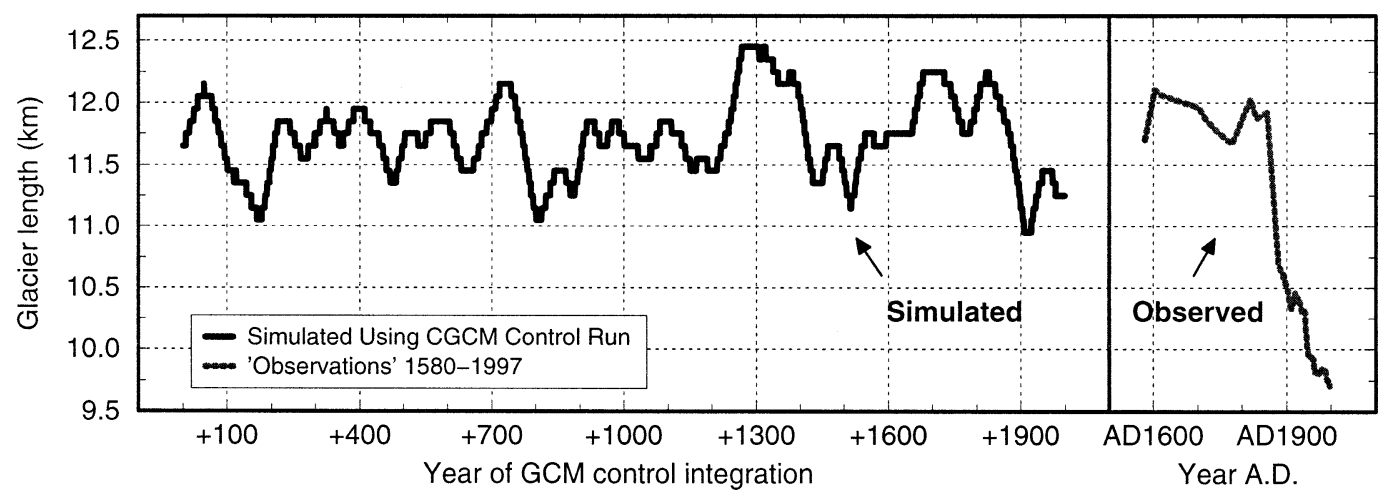

FIG. 6. Observed and simulated glacier fluctuations for (a) Nigardsbreen and (b) Rhonegletscher. Simulated glacier length fluctuations are exclusively due to internal variations in the climate system using AR processes from the downscaled control integration of the ECHAM4/OPYC coupled GCM.

\section{Distribution of Glacier Fluctuations}

a) Nigardsbreen

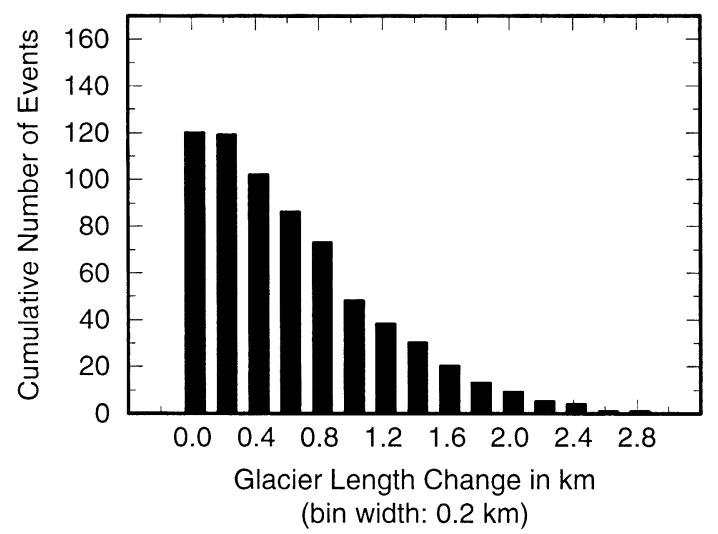

b) Rhonegletscher

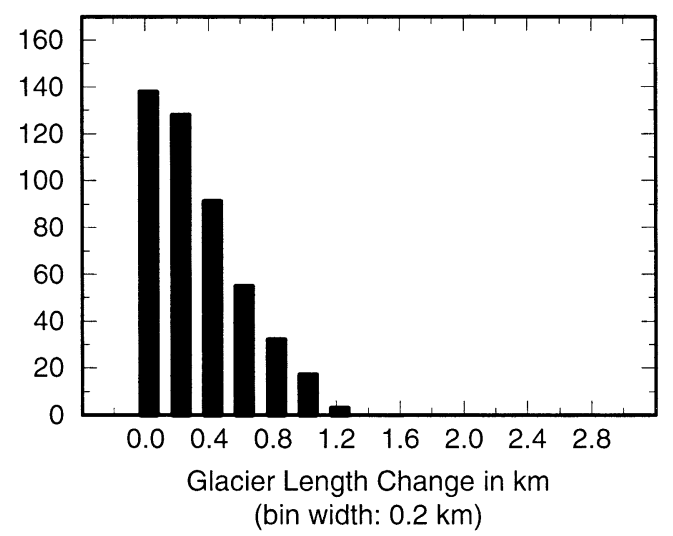

FIG. 7. Histogram of simulated glacier fluctuations using the downscaled coupled GCM integration. The cumulative number of events represents glacier length changes in the simulated 10000 -yr records with amplitudes larger than the value given on the abscissa (bin width: $0.2 \mathrm{~km}$ ). 


\section{Recurrence Relationships for Glacier Fluctuations \\ a) Nigardsbreen}

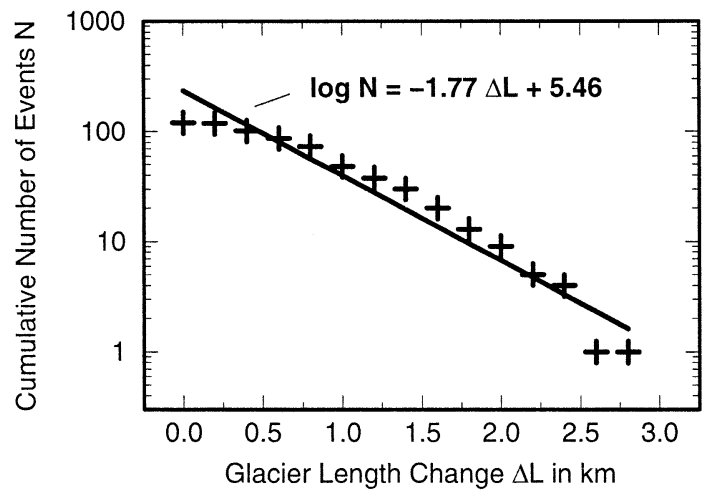

b) Rhonegletscher

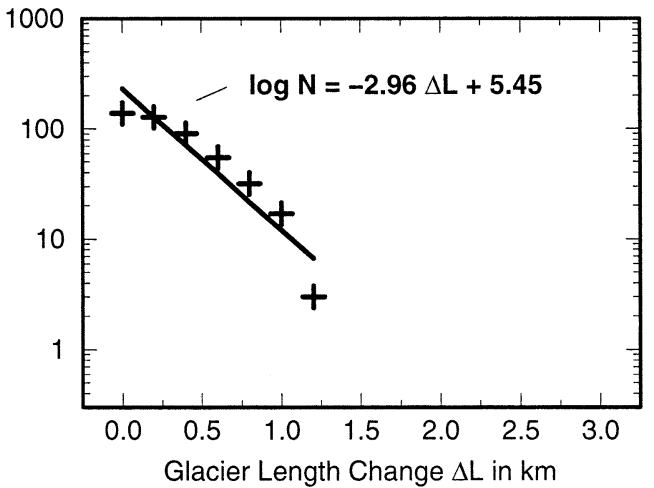

+ Simulated Using Coupled GCM Exponential Regression

FIG. 8. Recurrence relationships showing the cumulative number of glacier fluctuation events $N$ for a minimum glacier length change $\Delta L$ in the simulated 10000 -yr records. The relationships are well approximated by exponential regression.

$1 \mathrm{~km}$ can roughly be expected to occur every $250 \mathrm{yr}$ for Nigardsbreen and every $800 \mathrm{yr}$ for Rhonegletscher. The observed Little Ice Age to 1900 retreat of $2 \mathrm{~km}$ for Nigardsbreen can be expected with a return period of about $1500 \mathrm{yr}$ exclusively due to internal climate fluctuations. For extreme glacier length fluctuations of $3 \mathrm{~km}$ we find return period of about 8700 yr. For Rhonegletscher, the Little Ice Age to 1900 retreat of $1.5 \mathrm{~km}$ is expected to occur every $3700 \mathrm{yr}$. An extreme change of 2-km length has not been simulated for this glacier in the 10000 -yr record; however, in a longer integration we could expect it to occur with a return period of about 16000 yr. Figure 9 is a graphical illustration of return periods.

\section{d. Probabilities for the simulation of observed preindustrial glacier length changes and the present-day glacier retreat}

Probabilities for specific glacier fluctuations within a given time interval are calculated assuming that their occurrence generally follows a Poisson process (Priestley 1981). This approach also accounts for the fact that extreme glacier length changes that may not have been simulated in the $10000-\mathrm{yr}$ record still have a certain

TABLE 2. Return periods for specific glacier length fluctuations.

\begin{tabular}{ccc}
\hline \hline $\begin{array}{l}\text { Length } \\
\text { change }\end{array}$ & $\begin{array}{c}\text { Nigardsbreen } \\
(\mathrm{yr})\end{array}$ & $\begin{array}{c}\text { Rhonegletscher } \\
(\mathrm{yr})\end{array}$ \\
\hline$\Delta L \geq 0.5 \mathrm{~km}$ & 104 & 189 \\
$\Delta L \geq 1.0 \mathrm{~km}$ & 252 & 831 \\
$\Delta L \geq 1.5 \mathrm{~km}$ & 611 & 3650 \\
$\Delta L \geq 2.0 \mathrm{~km}$ & 1482 & 16023 \\
$\Delta L \geq 2.5 \mathrm{~km}$ & 3595 & $\left(\sim 1 \times 10^{5}\right)$ \\
$\Delta L \geq 3.0 \mathrm{~km}$ & 8725 & $\left(\sim 3 \times 10^{5}\right)$ \\
\hline
\end{tabular}

(although small) statistical probability of occurrence and may well occur in an even longer simulated record. The probability $P$ for the occurrence of a glacier length change $\Delta L$ (represented by its return period $\alpha$ ) within a time interval $T$ can be expressed as

$$
P(T, \alpha)=1-e^{-T / \alpha} .
$$

Substituting return period $\alpha$ with the definition in section $6 c$, we may write

$$
P(T, \Delta L)=1-\exp \left(-\frac{T}{T_{\text {sim }}} e^{b \Delta L+a}\right) .
$$

Here $T_{\text {sim }}$ is the length of simulated records, and $a$ and $b$ are the regression parameters obtained from the recurrence relationships.

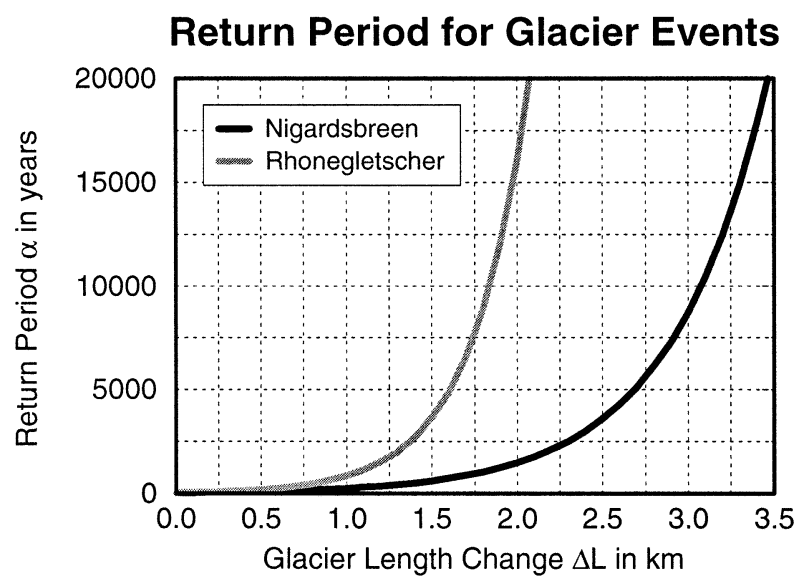

FIG. 9. Graphical illustration of return period $\alpha$ (yr) for glacier length changes larger than $\Delta L$ (in $\mathrm{km}$ ) for Nigardsbreen (solid line) and Rhonegletscher (shaded line). 
a) Probability of Nigardsbreen Glacier Fluctuations

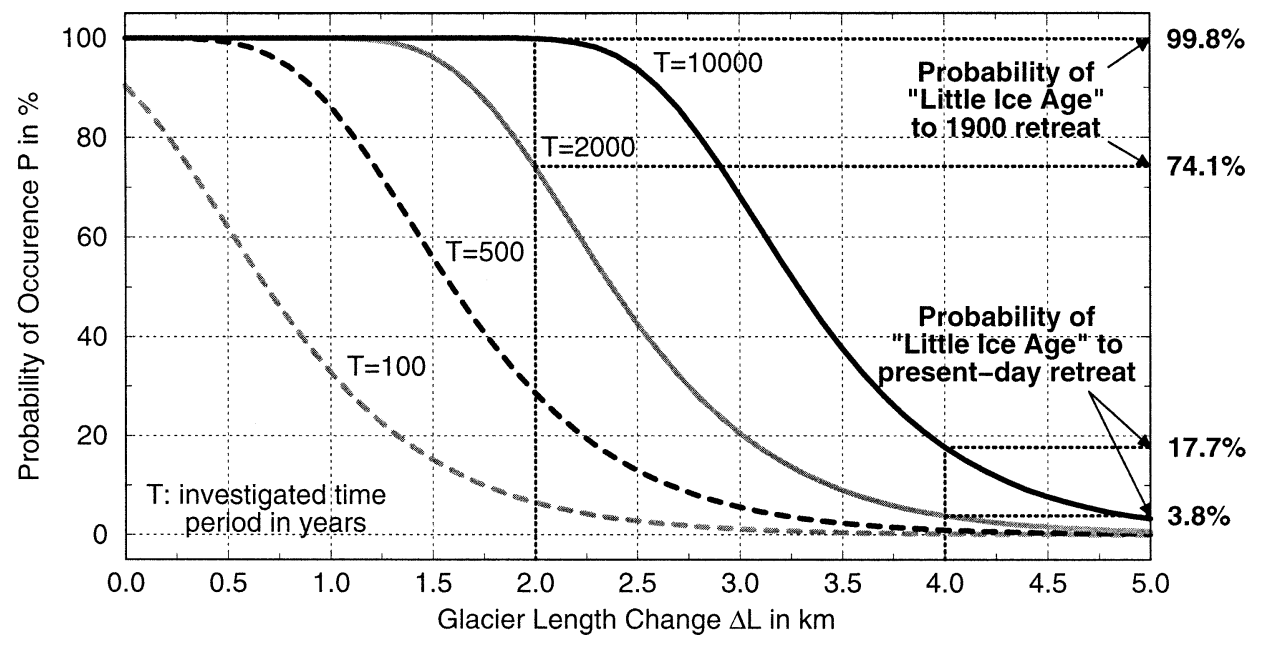

b) Probability of Rhonegletscher Glacier Fluctuations

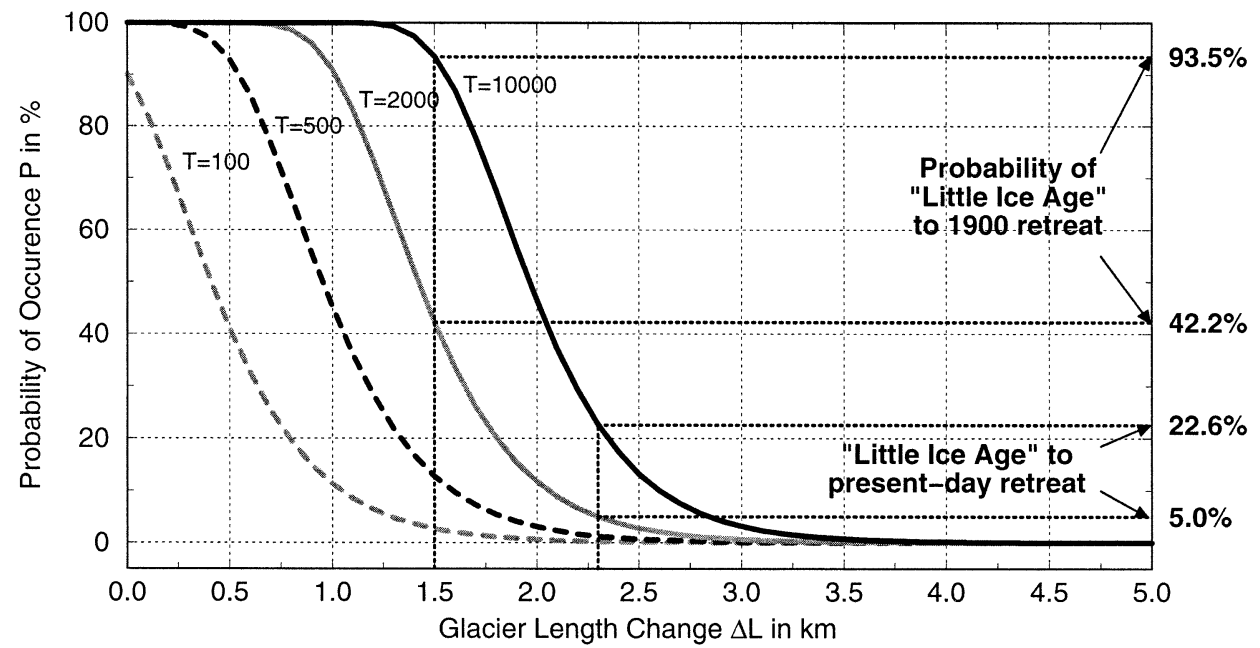

FIG. 10. Probabilities $P$ for the occurrence of simulated glacier length changes $\Delta L$ within a time period of investigation $T$, exclusively due to internal climate variations as simulated using the ECHAM4/OPYC coupled GCM. (a) For Nigardsbreen, the probability that observed preindustrial glacier length changes of $2 \mathrm{~km}$ (Little Ice Age to 1900 retreat) occur within a time period of $10000 \mathrm{yr}$ is $99.8 \%$, whereas the presentday retreat $(4 \mathrm{~km})$ is unlikely to be explained by internal variability $(P=17.7 \%)$. (b) For Rhonegletscher, the probabilities are $93.5 \%$ and $22.6 \%$, respectively.

The $P(T, \Delta L)$ relations for both Nigardsbreen and Rhonegletscher are illustrated in Fig. 10. We show probabilities of occurrence $P$ for glacier fluctuations $\Delta L$ within investigated time periods of $T=100, T=500$, $T=2000$, and $T=10000 \mathrm{yr}$.

For Nigardsbreen (Fig. 10a), the probability that observed preindustrial glacier length changes of $2 \mathrm{~km}$ (Little Ice Age to 1900 retreat, see Fig. 5) occur within a time period of $10000 \mathrm{yr}$ exclusively due to internal climate variations is $99.8 \%$ (Fig. 10a, solid line), these glacier fluctuations actually frequently occur in the simulated record (see Fig. 7). On the other hand, the observed Little Ice Age to present-day retreat of $4 \mathrm{~km}$ (see Fig. 5) has not been simulated due to internal climatic variability, the probability of occurrence is correspondingly small (17.7\%). Looking at a time period of 2000 yr only (Fig. 10a, shaded line), the probability of occurrence for preindustrial glacier fluctuations is still $74.1 \%$, whereas the probability for the present-day retreat drops to $3.8 \%$.

For Rhonegletscher (Fig. 10b), the probability of preindustrial glacier length changes within a 10000 -yr interval (solid line) is $93.5 \%$, for the present-day retreat it is $22.6 \%$. This means that the situation here is generally comparable to Nigardsbreen, preindustrial fluctuations are likely to occur in the simulated records whereas the present-day retreat is not simulated by any internal variation as represented by the coupled GCM. 


\section{Glacier Length Rates for 200-Year Windows a) Nigardsbreen}

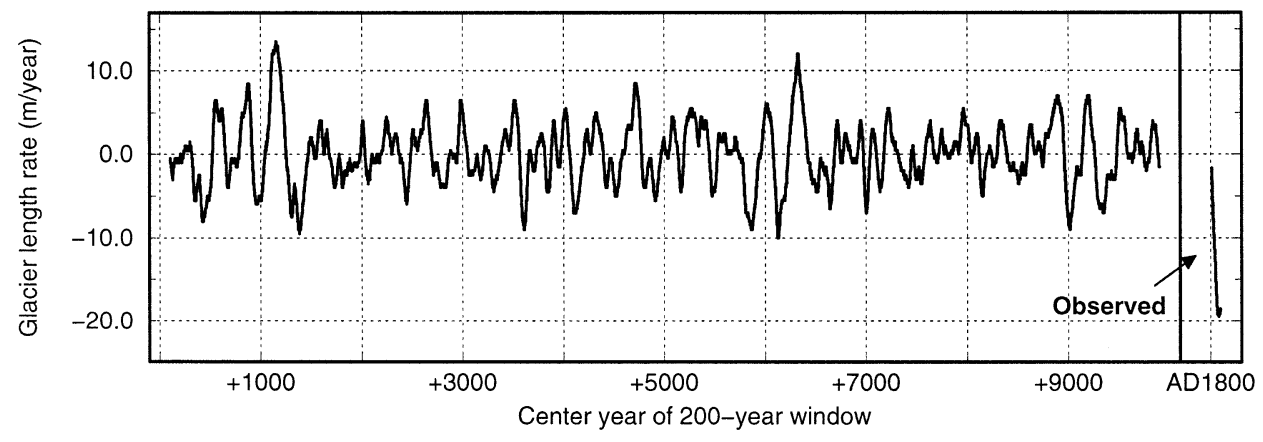

b) Rhonegletscher

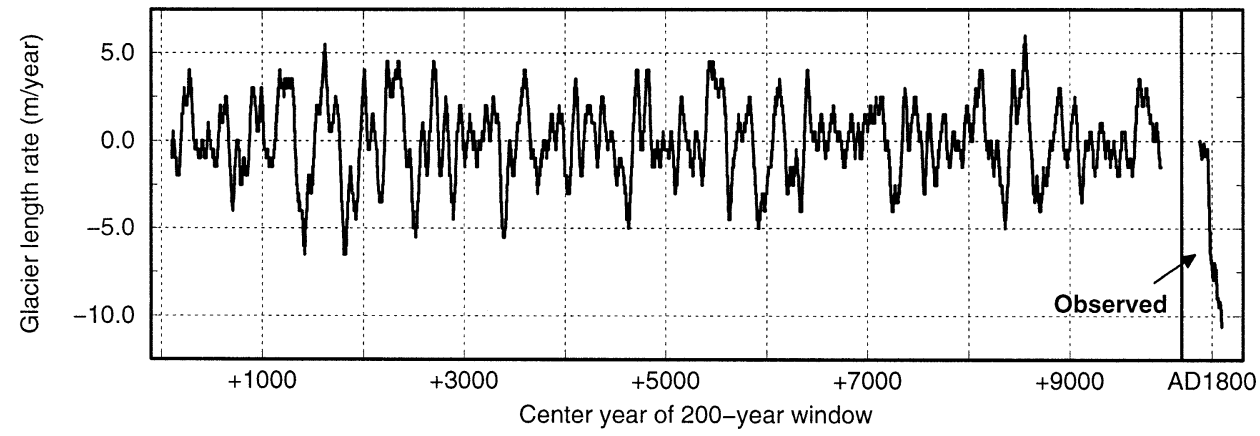

FIG. 11. Glacier length rates (unit: $\mathrm{m} \mathrm{yr}^{-1}$ ) for (a) Nigardsbreen and (b) Rhonegletscher calculated for 200-yr windows (abscissa shows center value) (left) moving over the entire 10 000-yr time period of simulations and (right) over the observational time periods. The observed negative length rates for both glaciers substantially exceed the simulated length rates for any 200 -yr time period within the $10000-y r$ records.

\section{e. Rates of glacier length changes}

Another perspective for the investigation of simulated and observed glacier length changes with time can be provided using rates of glacier length changes. Rates (unit: $\mathrm{m} \mathrm{yr}^{-1}$ ) of glacier advance/retreat for 200-yr time periods within both the 10000 -yr simulations and the observational data are shown in Fig. 11. It is evident that the observed negative length rates for both glaciers substantially exceed simulated length rates for any 200yr time period within the 10000 -yr records. No glacier retreat has been simulated due to internal climate variability that shows the same negative length rates over a 200-yr time interval as the observed retreat. This means that in addition to the total length changes of the present-day glacier retreat (as demonstrated above) we also find exceptional rates of change within $200-y r$ periods.

\section{Summary and conclusions}

In this study, we have applied a process-based modeling approach for the simulation of glacier fluctuations exclusively due to internal variations in the climate system using a downscaled coupled GCM experiment with
ECHAM4/OPYC. A mass balance model of intermediate complexity and a dynamic ice flow model have been used to simulate glacier fluctuations for Nigardsbreen (Norway) and Rhonegletscher (Swiss Alps). We have shown that local downscaling has a considerable impact on glacier fluctuations, the variability in glacier length is substantially increased compared to simply using direct coarse GCM gridpoint output. Simulated glacier fluctuations have been statistically analyzed in order to compare them to observed or reconstructed historical glacier length records. On the basis of recurrence relationships, return periods of specific glacier fluctuation events have been determined.

The observed retreat of Nigardsbreen since its "Little Ice Age maximum" until 1900, can be expected to occur roughly every $1500 \mathrm{yr}$ exclusively due to internal climate fluctuations as simulated by the coupled GCM experiment. For Rhonegletscher, such a retreat can be expected with a return period of about $3700 \mathrm{yr}$ due to internal variability. Calculations of probabilities consequently indicate that for both glaciers, fluctuations as observed or reconstructed before 1900 are simulated to occur in all likelihood due to internal climate variability. On the other hand, the observed present-day retreat of 
the glaciers has not been simulated in the experiments and is therefore very unlikely to be explainable by internal variations in the climate system.

We conclude that fluctuations of the investigated glaciers as far as observed or reconstructed before 1900, including their advance during the "Little Ice Age," can be explained by internal variations in the climate system as simulated by a GCM. This does not mean that other climatic forcing factors, for example, volcanic activity or solar irradiation changes may not partly contribute to explain observed glacier fluctuations. The impact of these factors, relative to internal climate variability, will increase with larger (up to hemispheric/ global) spatial scales. We show, however, that internal climate variations have a dominant impact when interpreting dynamic glacier records on at least regional scales. In order to broaden the basis for our conclusions we have additionally performed similar experiments using control integrations of the ECHAM4 model coupled to a mixed layer ocean model (ECHAM4/MLO; Roeckner 1997) and the second Hadley Centre Coupled Ocean-Atmosphere General Circulation Model (HadCM2; Johns et al. 1997) with results similar as described above (not shown). The impact of forced natural climate variability will be further investigated in future experiments using externally forced GCM integrations, also with recent studies in mind (Shindell et al. 2001) suggesting a potential impact of solar forcing on the European climate as a consequence of changes in the Arctic Oscillation/North Atlantic Oscillation (AO/ NAO).

An important point of this study derives from the fact that the present-day glacier retreat exceeds any simulated glacier fluctuation using the GCM control integrations. We have shown that it is consequently unlikely that this retreat can be entirely caused by internal climate variability and that external forcing must be a contributing factor. In additional experiments, we have investigated the role of anthropogenic forcing as a potential candidate. The process-based approach developed in this study has been applied to transient integrations with ECHAM4/OPYC forced by increasing concentrations of greenhouse gases, sulphate aerosols, and tropospheric ozone over the period 1860-2050 (Roeckner et al. 1999). In spite of a considerable impact of internal variations superimposed on the general trend over this period, first results for Nigardsbreen indicate that the observed present-day retreat is comparable to the simulated retreat expected due to anthropogenic forcing. The experiments therefore suggest that climate change due to anthropogenic forcing is a likely explanation for the observed glacier retreat. The transient GCM experiments predict a considerable future retreat of Nigardsbreen due to anthropogenic forcing, they indicate a retreat of about $20 \%$ of the present-day glacier length $(10.3 \mathrm{~km})$ by 2050 . Details of these experiments will be investigated in an additional study.

This study is spatially limited to the investigated gla- cier sites and only future experiments using a large number of globally distributed glaciers will allow conclusions on a global scale. However, our results are in line with recent studies (Haeberli et al. 1999; Dyurgerov and Meier 2000) indicating that rates and acceleration trends of global glacier mass changes over at least the past four decades correspond to the overall effects of anthropogenic forcing.

Acknowledgments. The authors would like to thank E. Roeckner, H. Graß1, D. Dommenget, J. Jones, and A. Tompkins for their valuable scientific support. Hans von Storch is thanked for help concerning several statistical issues within this study. We thank N. Noreiks for help on graphic representation. Glacier mass balance and glacier length data were obtained from the World Glacier Monitoring Service (WGMS), the ECMWF provided meteorological reanalyses, and the Swedish Meteorological and Hydrological Institute (SMHI) contributed operational weather station data. The study was supported by the European Commission under Contract ENV4-CT95-0072 and by NOAA Grant NA165P1616. The Alexander von Humboldt Foundation is thanked for supporting B. K. Reichert as a Feodor Lynen Fellow. Model simulations were performed at the German Climate Computing Center (DKRZ) in Hamburg, Germany.

\section{REFERENCES}

Bengtsson, L., 2001: Uncertainties of global climate prediction. Proc. Symp. on Global Biogeochemical Cycles in the Climate System, Jena, Germany, Max Planck Institute for Biogeochemistry, 1529.

— climate variability-What are their reasons? (in German). Energie und Umwelt-Wo Liegen Optimale Lösungen? J. Wolfrum and S. Wittig, Eds., Union der deutschen Akademien der Wissenschaften und Heidelberger Akademie der Wissenschaften, Springer Verlag, 27-57.

Box, G. E. P., and G. M. Jenkins, 1976: Time Series Analysis: Forecasting and Control. Holden-Day, 575 pp.

Bradley, R. S., and P. D. Jones, 1993: "Little Ice Age" summer temperature variations: Their nature and relevance to recent global warming trends. Holocene, 3, 367-376.

Cubasch, U. R., R. Voss, G. C. Hegerl, J. Waszkewitz, and T. J. Crowley, 1997: Simulation of the influence of solar radiation variations on the global climate with an ocean-atmosphere general circulation model. Climate Dyn., 13, 757-767.

Dyurgerov, M. B., and M. F. Meier, 2000: Twentieth century climate change: Evidence from small glaciers. Proc. Natl. Acad. Sci. USA, 97, 1406-1411.

Folland, C. K., and Coauthors, 2001: Observed climate variability and change. Climate Change 2001: The Scientific Basis, J. T. Houghton et al., Eds., Cambridge University Press, 99-181.

Gibson, J. K., P. Kållberg, S. Uppala, A. Nomura, A. Hernandez, and E. Serrano, 1997: ERA description. ECMWF Re-Analysis Project Report Series, Rep. 1 ECMWF, Reading, United Kingdom, $71 \mathrm{pp}$.

Grove, J. M., 1988: The Little Ice Age. Methuen, 498 pp.

Haeberli, W., 1995: Glacier fluctuations and climate change detection. Geogr. Fis. Dinam. Quat., 18, 191-199.

, R. Frauenfelder, M. Hoelzle, and M. Maisch, 1999: On rates and acceleration trends of global glacier mass changes. Geogr. Annal., 81, 585-591. 
Hansen, J., I. Fung, R. Ruedy, and M. Sato, 1992: Potential climate impact of Mount Pinatubo eruption. Geophys. Res. Lett., 19, 215-218.

Hasselmann, K., 1976: Stochastic climate models I: Theory. Tellus, 28, 473-485.

Hoelzle, M., and W. Haeberli, 1999: World glacier monitoring service, world glacier inventory. National Snow and Ice Data Center, University of Colorado, Boulder, CO. [Available by e-mail request to nsidc@kryos.colorado.edu]

Houghton, J. T., G. J. Jenkins, and J. J. Ephraums, Eds.,1990: Climate Change: The IPCC Scientific Assessment. Cambridge University Press, $364 \mathrm{pp}$.

Hoyt, D. V., and K. H. Schatten, 1993: A discussion of plausible solar irradiance variations 1700-1992. J. Geophys. Res., 98, 18 895-18906.

Hughes, M. K., and H. F. Diaz, 1994: Was there a "Medieval Warm Period" and if so where and when? Climatic Change, 26, 109142.

Johns, T. C., R. E. Carnell, J. F. Crossley, J. M. Gregory, J. F. B. Mitchell, C. A. Senior, S. F. B. Tett, and R. A. Wood, 1997: The Second Hadley Centre coupled ocean-atmosphere GCM: Model description, spinup and validation. Climate Dyn., 13, 103-134.

Lamb, H. H., 1977: Climatic History and the Future. Vol. 2, Climate: Present, Past and Future, Methuen, 835 pp.

Lean, J., J. Beer, and R. S. Bradley, 1995: Reconstruction of solar irradiance since 1610: Implications for climate change. Geophys. Res. Lett., 22, 3195-3198.

Lindzen, R. S., and C. Giannitsis, 1998: On the climatic implications of volcanic cooling. J. Geophys. Res., 103, 5929-5941.

Mikolajewicz, U., and E. Maier-Reimer, 1990: Internal secular variability in an ocean general circulation model. Climate Dyn., $\mathbf{4}$, $145-156$.

Oberhuber, J. M., 1993: Simulation of the Atlantic circulation with a coupled sea ice-mixed layer-isopycnal general circulation model. Part I: Model description. J. Phys. Oceanogr., 23, 808829.

Oerlemans, J., 1992: Climate sensitivity of glaciers in southern Norway: Application of an energy-balance model to Nigardsbreen, Helstugubreen, and Alfotbreen. J. Glaciol., 38, 223-232.

, 1997: A flow-line model for Nigardsbreen: Projection of future glacier length based on dynamic calibration with the historic record. Ann. Glaciol., 24, 382-389.

_ 2000 : Holocene glacier fluctuations: Is the current rate of retreat exceptional? Ann. Glaciol., 31, 39-44.

__ 2001: Glaciers and Climate Change. Balkema Publishers, 148 pp.

__ , and B. K. Reichert, 2000: Relating glacier mass balance to meteorological data using a seasonal sensitivity characteristic (SSC). J. Glaciol., 46, 1-6.

Paterson, W. S. B., 1994: The Physics of Glaciers. 3d ed. Pergamon, $480 \mathrm{pp}$.

Priestley, M. B., 1981: Spectral Analysis and Time Series. Academic Press, 890 pp.

Reichert, B. K., L. Bengtsson, and O. Åkesson, 1999: A statistical modeling approach for the simulation of local paleoclimatic proxy records using general circulation model output. J. Geophys. Res., 104, $19071-19083$.

, _ _ , and J. Oerlemans, 2001: Midlatitude forcing mechanisms for glacier mass balance investigated using general circulation models. J. Climate, 14, 3767-3784.

Roeckner, E., 1997: Climate sensitivity experiments with the MPI/ ECHAM4 model coupled to a slab ocean (abstract). Euroclivar Workshop on Cloud Feedbacks and Climate Change, C. A. Senior and J. F. B. Mitchell, Eds., Hadley Centre for Climate Prediction and Research, 20.

— el ECHAM-4: Model description and simulation of present-day climate. Max Planck Institute for Meteorology Rep. 218, Hamburg, Germany, 90 pp.

_ L. Bengtsson, J. Feichter, J. Lelieveld, and H. Rodhe, 1999: Transient climate change simulations with a coupled atmosphere-ocean GCM including the tropospheric sulfur cycle. $J$. Climate, 12, 3004-3032.

Sarachik, E. S., M. Winton, and F. L. Yin, 1996: Mechanisms for decadal-to-centennial climate variability. Decadal Climate Variability, D. L. T. Anderson and J. Willebrand, Eds., NATO ASI Series, Vol. 44, Springer, 157-210.

Shindell, D. T., G. A. Schmidt, M. E. Mann, D. Rind, and A. Waple, 2001: Solar forcing of regional climate change during the Maunder Minimum. Science, 294, 2149-2152.

von Storch, H., and F. W. Zwiers, 1999: Statistical Analysis in Climate Research. Cambridge University Press, 484 pp. 